\title{
Effects of Caprylic Acid on Performance and Mortality of Growing Rabbits
}

\author{
V. SKŘIVANOVÁ ${ }^{1}$, M. MAROUNEK ${ }^{2}$ \\ ${ }^{1}$ Research Institute of Animal Production, Prague, Czech Republic \\ ${ }^{2}$ Institute of Animal Physiology and Genetics, Czech Academy of Sciences, Prague, Czech Republic \\ Received July 12, 2002 \\ Accepted November 18, 2002 \\ Abstract \\ Skřivanová V., M. Marounek: Effects of Caprylic Acid on Performance and Mortality \\ of Growing Rabbits. Acta Vet. Brno, 2002 71: 435-439. \\ Caprylic acid (C8:0) is a compound present in the rabbit milk, active against a variety of \\ microorganisms. The aim of our study was to evaluate the effect of caprylic acid on growth and \\ mortality of young rabbits. Caprylic acid was added to granulated feed at 0,2 and $5 \mathrm{~g} / \mathrm{kg}$. Two \\ feeding trials on different farms were carried out using weaned Hyla 2000 and Hyplus rabbits, \\ 5 weeks old at the start of the experiment (altogether 288 rabbits). Caprylic acid had no \\ significant effect on total weight gains in either trial. No adverse effect of caprylic acid on feed \\ intake was observed. The mortality of rabbits fed diets with caprylic acid at 0 and $5 \mathrm{~g} / \mathrm{kg}$ was \\ 16.7 and $0 \%(P<0.05)$, and 9.3 and $2.0 \%$ in the $1^{\text {st }}$ and the $2^{\text {nd }}$ trial, respectively. It can be \\ concluded that caprylic acid is capable to decrease mortality of young rabbits. Its use seems to \\ be more effective on farms where rabbit mortality is high. \\ Antibiotics alternative, fatty acid, growth
}

Rabbit breeding is an important branch of animal production. Rabbit meat is of high quality and safety. The susceptibility of rabbits to various infections diseases and high mortality of young rabbits after weaning, however, hinder the development of the rabbit industry. Weanling rabbits often suffer from diarrhoea, which is the major cause of their mortality. Rabbit breeders widely use antibiotics to control enteritis infections. The use of antibiotics, however, is viewed critically in recent times. Some were banned totally, some received no renewal of their license as a measure of preventive consumer protection. There is a pressing need for harmless antimicrobial substances suitable for rabbits nowadays.

In 1965, Smith found that suckling rabbits were unique among seven animal species studied in that their contents of the stomach and small intestine were almost completely sterile. Canas-Rodriguez and Smith (1966) suggested that the rabbit milk fat contained antimicrobial compounds, identified as eight and ten carbon saturated fatty acids (caprylic and capric acid, respectively). Content of these acids in the rabbit milk is very high, they represent from one third to one half of the total fatty acids in the rabbit milk fat (Christ et al. 1996; Lebas et al. 1996). Both acids are practically absent from the feed, thus, rabbits synthesize them in the mammary gland. Bactericidal effect of fatty acids is well known (Nieman 1954; Galbraith et al. 1971; Galbraith and Miller 1973; Henderson 1973; Maczulak et al. 1981; Chalupa et al. 1984). Fatty acids penetrate bacterial membranes, interfere with the metabolism of energy within cells and disturb energydependent processes (Galbraith and Miller 1973). Fatty acids bound in triacylglyceroles (triglycerides) did not influence in vitro rumen fermentation (Chalupa et al. 1984). The hydrolysis of milk fat by lipase(s) is thus the prerequisite of their antimicrobial action. Antimicrobial activity of caprylic and capric acid confirmed Marounek et al. (2002).

The aim of this study was to test the hypothesis that addition of caprylic acid to a feed mixture could improve health and performance of young rabbits. Two experiments on

Address for correspondence:

Doc. Ing. V. Skřivanová, CSc.

Research Institute of Animal Production

Prague 10 - Uhríněves
Phone: +420 267009680

Fax: +420267770779

http//www.vuzv.cz 
different commercial farms were carried out. For a long time these farms have different results as far as the performance and mortality of rabbits is concerned.

\section{Materials and Methods}

$1^{\text {st }}$ experiment

A total of 126 weaned rabbits of both sexes (Hyla 2000 breed), 35-day-old at the beginning of experiment, were divided into 3 groups. Rabbits were kept in standard fattening all-wire cages, four per cage. Environmental conditions were as follows: temperature $15-17^{\circ} \mathrm{C}$, relative humidity $c a 65 \%, 12: 12 \mathrm{~h} \mathrm{light}$ : dark daily photoperiod cycle. Rabbits of the first group were fed a basal diet (Table 1). Rabbits of the second group were fed the same diet supplemented with caprylic acid (Fluka) at $2 \mathrm{~g} / \mathrm{kg}$. Rabbits of the third group were fed the diet with caprylic acid added at $5 \mathrm{~g} / \mathrm{kg}$. Rapeseed oil concentration in the feed was correspondingly decreased. All diets were granulated and supplemented with Robenidin (a coccidiostat) at $66 \mathrm{mg} / \mathrm{kg}$. Feed consumption per group was measured weekly. The weights of individual rabbits were recorded in two-week intervals. Samples of faeces were examined microscopically for the presence of Eimeria oocysts in the State Veterinary Institute, Prague. In the same institute dead rabbits were examined using standard pathological, bacteriological and parasitological methods. The experiment lasted for 42 days.

Table 1

Ingredients and determined chemical composition of the basal diet ${ }^{\mathrm{a}}$

\begin{tabular}{|l|c|l|c|}
\hline \multicolumn{2}{|c|}{ Ingredients (\%) } & \multicolumn{2}{c|}{ Composition (g/kg) } \\
\hline Wheat bran & 27 & Dry matter & 898 \\
\hline Sugarbeet pulp & 26 & Crude protein & 159 \\
\hline Alfalfa meal & 14 & Fibre & 370 \\
\hline Oats & 8 & Fat & 126 \\
\hline Extracted sunflower meal & 7 & Starch & 68 \\
\hline Barley & 6.5 & Ash & \\
\hline Yeast & 5 & & \\
\hline Extracted soyabean meal & 2 & & \\
\hline Rapeseed oil & 1.5 & & \\
\hline Mineral supplement & 1 & & \\
\hline Vitamin supplement ${ }^{\mathrm{c}}$ & 1 & & \\
\hline Dicalcium phosphate & 0.7 & & \\
\hline Salt & 0.3 & & \\
\hline
\end{tabular}

${ }^{\text {a }}$ Experimental diets were supplemented with 2 and $5 \mathrm{~g}$ of caprylic acid per $\mathrm{kg}$

${ }^{\mathrm{b}}$ Composition $\left(\mathrm{kg}^{-1}\right): \mathrm{Ca}-222 \mathrm{~g}, \mathrm{P}-62 \mathrm{~g}, \mathrm{Na}-34 \mathrm{~g}, \mathrm{Fe}-5.6 \mathrm{~g}, \mathrm{Mn}-4.6 \mathrm{~g}, \mathrm{Zn}-4.1 \mathrm{~g}, \mathrm{Cu}-710 \mathrm{mg}, \mathrm{I}-22 \mathrm{mg}$, $\mathrm{Se}-9 \mathrm{mg}$.

c Composition $\left(\mathrm{kg}^{-1}\right)$ : Vitamin A - 1200.000 IU, Vitamin $\mathrm{D}_{3}-100.000 \mathrm{IU}$, Vitamin E - $5 \mathrm{~g}$, Niacin - $5 \mathrm{~g}$, Pantothenate $-2 \mathrm{~g}$, Riboflavin $-0.7 \mathrm{~g}$, Thiamine $-0.2 \mathrm{~g}$, Pyridoxine $-0.2 \mathrm{~g}$, Folic acid $-30 \mathrm{mg}$, Biotin $-20 \mathrm{mg}$, Cobalamin $-2 \mathrm{mg}$, Choline $-60 \mathrm{~g}$, Lysine $-25 \mathrm{~g}$, Methionine $-10 \mathrm{~g}$, Antioxidant $-10 \mathrm{~g}$.

One-way analysis of variance was used to evaluate the effects of caprylic acid. Comparison of means was done by the Bonferroni test, where appropriate. The effect of caprylic acid on the mortality of rabbits was evaluated by the $\chi^{2}$-test.

$2^{\text {nd }}$ experiment

The same diets and experimental arrangement were used in the second experiment, on another farm. A total of 162 weaned rabbits (Hyplus breed), 35-day-old at the beginning of experiment were used. Environmental conditions on this farm were as follows: temperature $16-18{ }^{\circ} \mathrm{C}$, relative humidity not exceeding $68 \%, 12: 12 \mathrm{~h}$ light : dark daily photoperiod cycle.

\section{Results and Discussion}

On average, control rabbits gained 32.4 and $41.0 \mathrm{~g}$ per day in the $1^{\text {st }}$ and $2^{\text {nd }}$ experiment, respectively (Table 2 and 3). Caprylic acid had no significant effect on total 
Table 2

Effect of caprylic acid on performance and mortality of growing rabbits. Results of the $1^{\text {st }}$ experiment

\begin{tabular}{|l|c|c|c|}
\hline \multirow{2}{*}{} & \multicolumn{3}{|c|}{ Caprylic acid addition $(\mathrm{g} / \mathrm{kg})$} \\
\cline { 2 - 4 } & 0 & 2 & 5 \\
\hline Number of rabbits & 42 & 42 & $939 \pm 99$ \\
\hline Initial live weight $(\mathrm{g})$ & $940 \pm 115$ & $957 \pm 109$ & $2331 \pm 238$ \\
\hline Final live weight $(\mathrm{g})$ & $2299 \pm 304$ & $2371 \pm 308$ & $30.1 \pm 4.0^{\mathrm{b}}$ \\
\hline Daily gain $(\mathrm{g})$ & & & $34.3 \pm 5.0^{\mathrm{b}}$ \\
\hline 6. -7. wk of age & $27.9 \pm 4.7^{\mathrm{ab}}$ & $27.7 \pm 4.0^{\mathrm{a}}$ & $35.4 \pm 6.6^{\mathrm{b}}$ \\
\hline $8 .-9$. wk of age & $28.9 \pm 6.9^{\mathrm{a}}$ & $31.1 \pm 5.7^{\mathrm{a}}$ & $33.1 \pm 6.4$ \\
\hline $10 .-11$. wk of age & $41.5 \pm 7.8^{\mathrm{a}}$ & $43.0 \pm 9.4^{\mathrm{a}}$ & 193 \\
\hline 6. -11. wk of age & $32.4 \pm 7.7$ & $33.7 \pm 7.6$ & 3.30 \\
\hline Feed intake per group $(\mathrm{kg})$ & 157 & 187 & 0 \\
\hline Feed conversion $(\mathrm{kg} / \mathrm{kg})$ & 3.31 & 3.23 & 0 \\
\hline Mortality & & & 0 \\
\hline $6 .-7$. wk of age & 4 & 0 & $0^{\mathrm{b}}$ \\
\hline $8 .-9$. wk of age & 2 & $1^{\text {ab }}(2.4 \%)$ & \\
\hline $10 .-11$. wk of age & $7^{\mathrm{a}}(16.7 \%)$ & & \\
\hline 6. -11. wk of age & & & \\
\hline
\end{tabular}

Means \pm SD

${ }^{\mathrm{ab}}$ Values in the same row with different superscripts differ significantly $(P<0.05)$

weight gains in either experiment. No adverse effect of caprylic acid on feed intake was observed. The feed intake, however, was measured per group, thus the statistical evaluation of this trait was not possible. Out of 288 animals, 16 rabbits died in the course of both experiments, 8 in the course of the $1^{\text {st }}$ experiment and 8 in the course of the $2^{\text {nd }}$ experiment. Necropsy of dead rabbits revealed enteritis, catarrh of lungs, hyperaemia of liver, hyperaemia of kidney and spleen, hyperaemia of lungs, and poor nutritional status. Bacterial pathogens were identified as Pasteurella multocida, Clostridium perfringens and Bordetella bronchiseptica. Twelve control and 4 treated rabbits died. Treated rabbits died due to a respiratory disease ( 3 animals) and due to enteritis ( 1 rabbit). Few faecal samples were free of coccidia in the first two weeks of experiment. The intensity of infection by Eimeria sp. was lower on the $2^{\text {nd }}$ farm, where most rabbits were infected only slightly $(+)$, than on the $1^{\text {st }}$ farm $(++)$. E. magna and E. perforans oocysts were observed more frequently than oocysts of other Eimeria species. The effect of caprylic acid on oocyst shedding was not noticeable, possibly because of low intensity of infection.

In the $1^{\text {st }}$ experiment, mortality of control rabbits and those fed caprylic acid at $5 \mathrm{~g} / \mathrm{kg}$ was 16.7 and $0 \%(P=0.018)$. Caprylic acid at this concentration decreased mortality of rabbits also in the $2^{\text {nd }}$ experiment (from 9.3 to $2.0 \%$ ), but its effect was not statistically significant. (Di erick et al. 2002) observed that the controlled release of medium-chain fatty acids $\left(\mathrm{C}_{6}-\mathrm{C}_{12}\right)$ from coconut and Cuphea seeds oils resulted in significant suppression of the intestinal flora (total anaerobic count, lactobacilli, E. coli), improved mucosal health and growth performance of piglets. We are not aware of any other study on use of medium-chain fatty acids in nutrition of other animal species. Caprylic acid exerts both antibacterial and antiviral activity (Isaacs et al. 1995). Further experimentation is needed to specify its health-promoting effect in rabbits in more details. 
Table 3

Effect of caprylic acid on performance and mortality of growing rabbits. Results of the $2^{\text {nd }}$ experiment

\begin{tabular}{|l|c|c|c|}
\hline \multirow{2}{*}{} & \multicolumn{3}{|c|}{ Caprylic acid addition $(\mathrm{g} / \mathrm{kg})$} \\
\cline { 2 - 4 } & 0 & 2 & 5 \\
\hline Number of rabbits & 54 & 94 & 54 \\
\hline Initial live weight $(\mathrm{g})$ & $956 \pm 85$ & $2602 \pm 227$ & $2580 \pm 252$ \\
\hline Final live weight $(\mathrm{g})$ & $2680 \pm 257$ & & $36.3 \pm 4.3^{\mathrm{b}}$ \\
\hline Daily gain $(\mathrm{g})$ & & $38.4 \pm 3.3^{\mathrm{a}}$ & $37.1 \pm 5.5$ \\
\hline $6 .-7$. wk of age & $36.7 \pm 4.7^{\mathrm{ab}}$ & $37.2 \pm 4.1$ & $43.3 \pm 7.2^{\mathrm{b}}$ \\
\hline $8 .-9$. wk of age & $39.1 \pm 6.5$ & $46.2 \pm 6.5^{\mathrm{ab}}$ & $38.8 \pm 6.2$ \\
\hline $10 .-11$. wk of age & $48.5 \pm 7.3^{\mathrm{a}}$ & $39.4 \pm 5.3$ & 327 \\
\hline 6. -11. wk of age & $41.0 \pm 6.3$ & 349 & 3.72 \\
\hline Feed intake per group $(\mathrm{kg})$ & 291 & 3.91 & 0 \\
\hline Feed conversion $(\mathrm{kg} / \mathrm{kg})$ & 3.45 & & 1 \\
\hline Mortality & & 0 & 0 \\
\hline $6 .-7$. wk of age & 0 & 2 & $1(2.0 \%)$ \\
\hline $8 .-9$. wk of age & 3 & 0 & \\
\hline $10 .-11$. wk of age & $5(9.3 \%)$ & & \\
\hline $6 .-11$. wk of age & & & \\
\hline
\end{tabular}

Means \pm SD

${ }^{a b}$ Values in the same row with different superscripts differ significantly $(P<0.05)$

\section{Účinek kyseliny kaprylové na užitkovost a úhyny brojlerových králíků}

Kyselina kaprylová (C8:0) je látka s výraznými antimikrobiálními vlastnostmi, přítomná v mléce králíků. Cílem našich pokusů bylo zjistit účinek této sloučeniny na růst a úhyny mladých králíků ve výkrmu. Kyselinu kaprylovou jsme přidali do granulované krmné směsi v množství 0,2 a $5 \mathrm{~g} / \mathrm{kg}$, a uskutečnili dva pokusy na různých farmách s odstavenými králíky genotypů Hyla 2000 a Hyplus, věku 5 týdnů na začátku sledování (celkem 288 zvířat). V žádném z pokusů neměla kyselina kaprylová vliv na př́růstky hmotnosti. Nepozorovali jsme ani záporný účinek na př́jem krmiva. Úhyny králíků v kontrolních skupinách 1. a 2. pokusu byly 16,7 a 9,3\%. U králíků přijímajících krmivo s 5 g kyseliny kaprylové v $1 \mathrm{~kg}$ byly odpovídající úhyny 0 a $2 \%$. V 1.pokuse byl tento rozdíl statisticky významný $(P=$ 0.018). Lze učinit závěr, že kyselina kaprylová je použitelná ke snížení úhynů mladých králíků, na farmách, kde úhyny přesahují únosnou mez.

\section{Acknowledgement}

This study received financial support from the Grant Agency of the Czech Republic (project No. 523/02/0460).

\section{References}

CANAS - RODRIGUEZ, A, SMITH, HW 1966: The identification of the antimicrobial factors of the stomach content of suckling rabbits. Biochem J 10: 79-82

CHALUPA, W, RICKABAUGH, B, KRONFELD, DS, SKLAN, D 1984: Rumen fermentation in vitro as influenced by long chain fatty acids. J Dairy Sci 67: 1439-1444

CHRIST, B, LANGE, L, JEROCH, H 1996: Effect of dietary fat on fat content and fatty acid composition of does milk. In: Lebas F. (ed) Proceedings of the $6^{\text {th }}$ World Rabbit Congress, vol. 1, AFC Lempdes (France), pp. $135-138$

DIERICK, N, DECUYPERE J. A, MOLLY, K, VAN BEEK, E, VANDERBEKE, E 2002: Medium chain fatty acids as a nutraceutical alternative for in-feed antibiotics in piglet nutrition. Reprod Nutr Dev 42: (Suppl 1), S18 
GALBRAITH, H MILLER, TB 1973: Effect of long chain fatty acids on bacterial respiration and amino acid uptake. J Appl Bacteriol 36: 659-675

GALBRAITH, H, MILLER, TB, PATON, AM, THOMPSON, JK 1971: Antibacterial activity of long chain fatty acids and the reversal with calcium, magnesium, ergokalciferol and cholesterol. J Appl Bacteriol 34: 803-813 HENDERSON, C 1973: The effects of fatty acids on pure cultures of rumen bacteria. J Agric Sci (Camb) 81: $107-112$

ISAACS, CE, LITOV, RE, THORMAR, H 1995: Antimicrobial activity of lipids added to human milk, infant formula, and bovine milk. Nutr Biochem 6: 362-366

LEBAS, F, LAMBOLEY, B, FORTUN - LAMOTHE, L 1996: Effects of dietary energy level and origin (starch $v s$ oil) on gross and fatty acid composition of rabbit milk. In: Lebas, F (Ed) Proceedings of the $6^{\text {th }}$ World Rabbit Congress, vol. 1, AFC Lempdes (France) pp. 135-138

MACZULAK, AE, DEHORITY, BA, PALMQUIST, DL 1981: Effects of long-chain fatty acids on growth of rumen bacteria. Appl Environ Microbiol 42: 856-862

MAROUNEK, M, SKŘIVANOVÁ, V, SAVKA, O 2002: Effect of caprylic, capric and oleic acid on growth of rumen and rabbit caecal bacteria. J Anim Feed Sci 11: 507-516

NIEMAN, C 1954: Influence of trace amounts of fatty acids on the growth of microoganisms. Bacteriol Rev 18 : $147-163$

SMITH, HW 1965: The development of the flora of the alimentary tract in young animals. J Path Bacteriol 90: 495-513 